Integritas 3.1 (Spring 2014), pp. 23-26.

doi: 10.6017/integritas.v3i1p23

\title{
Response to Marc Muskavitch
}

\section{William Werpehowski}

Marc Muskavitch's essay displays the virtues of both an excellent teacher and a fine scholar. It is clear in its order and argument and presents difficult material, especially to the uninitiated, in a manner that is both concise and leisurely. His constructive proposals are insightful and theologically significant. I want to express my appreciation and gratitude by way of two questions with commentary and a concluding observation.

I. What social and cultural purposes do appeals to and defenses of determinism, generally speaking, serve? And how may genetic determinism specifically work in this regard? To get our bearings we might think here of the "Enlightenment project," where celebration of the predictive power of natural science appeared to go hand in hand with an attack on religious domination and superstition on the one hand, and cultural confidence in steady human progress and even historical perfectibility on the other. More recently, consider novelist and social critic Marilynne Robinson's spirited critique of what she calls "parascience," a pseudo-scientific, deterministic, finally positivist inquiry that relies on "sociobiology" to rule out of our universe the reality of "mind," that is, human self-consciousness and subjectivity as free and creative mystery, and, with that, the very possibility of altruism.

Our positivist writers on human nature assume that only self-interest can account for human behavior. Selfish behavior is assumed to be merely reflexive, though it can be deceptive in its forms, for example when the reward toward which it is directed is social approval. And the deep and persisting acceptance of this vision as indisputable truth has had an epochal significance for the way we think. ${ }^{1}$

1 Marilynne Robinson, Absence of Mind (New Haven and London: Yale University Press, 2010), 38.

William Werpehowski is the Robert L. McDevitt, K.S.G., K.C.H.S. and Catherine H. McDevitt, L.C.H.S. Chair in Catholic Theology at Georgetown University. A former president of the Society of Christian Ethics, Dr. Werpehowski was director of Villanova's Center for Peace and Justice Education from 1999-2010. He is the author of American Protestant Ethics and the Legacy of H. Richard Niebuhr, and co-editor, with Gilbert Meilaender, of the Oxford Handbook of Theological Ethics. 
For example, and not to put too fine a point on the matter, love is a cheat; it's a dogeat-dog world in which only the strong survive. Capitalist political economies built on versions of "the invisible hand," and assumptions of universal self-interest, are without question good for us, as they go with the flow of our common human nature.

I suggest that deterministic frameworks along with their predictive power can define dualisms that divide and oppose human identities to one another. So there's "us"- the saved, the civilized—set over against "them" — the damned, the "primitive" —as each set is theologically and culturally fated, respectively. Hence genetically determinist accounts of the "well" and the "unwell" can pave the way for a kind of exclusion ranging from being denied affordable health care to being denied life itself because one has trisomy 2I. I do not want to press this suggestion too far; after all, denials of our fatedness can also be exclusionary. As Peter Brown has shown, Pelagianism was a case in point. ${ }^{2}$ So is a strictly meritocratic case for an "opportunity society." Nevertheless, both here and there we should be on guard.

2. What are the factors that underlie our desire to predict the future in these and other cases? An admittedly suspicious response to the question will focus on an interest in control and, just so, in managing our future and that of others as thoroughly as possible. We would elevate ourselves beyond our contingency in the attempt to deny it. We are taught and will teach an ideal of self-possession that carries with it an aversion to risk, the rejection of precarity, and, perhaps, a reluctance to "go forth" ${ }^{3}$ from our comfort zones, from our cunningly crafted "life plans," toward others, from and in view of our shared vulnerability. Think of some of the "decisions" Marc describes regarding embryo and fetal "selection."

Here as well, we ought not go too far with this line of thought. We properly seek to be provident and careful about our lives. An interest in predicting or gaining a sense of how things could or will go need not, of course, carry the dispositions I just presented. We make fitting decisions all the time about likelihoods concerning admission to a school, enjoying a job or a vacation spot, a medical prognosis and alternative therapies, and so forth. And note that these cases tell us that the relevant field of prudent choices includes many situations that have nothing to do with genetic determinism.

3. About living in a state grace, Marc writes:

... it may be that that coming to dwell within a "state of grace" could affect mind-body interactions (e.g., psychoneuroimmunology) in ways that prevent or reverse disease, or reduce its severity, despite the fact our genetic or epigenetic constitution predisposes us toward ill health.

In the context of our discussion, we might consider that we could dwell within a "state of grace" for any of a number of reasons. We might believe ourselves

2 Peter Brown, Religion and Society in the Age of St. Augustine (Eugene, OR: Wipf \& Stock, 2007), 183207.

3 Pope Francis, The Joy of the Gospel, http://w2.vatican.va/content/francesco/en/apost_exhortations/ documents/papa-francesco_esortazione-ap_20131124_evangelii-gaudium.html, par. 20-24. 
to be the beneficiaries of the grace of a loving God, to be supported by loving family and friends, to be privy to a transcendent reality, to understand essential deep truths, to be one with the universe, to be at peace, to be experiencing flow, to be living in mindfulness, to have achieved detachment. Why would arriving in such "places" improve our wellness, even in the face of predispositions toward disease?

An expanding corpus of evidence reveals that interactions among our psychology, our bodies, and our physiology can shape powerfully our health and well-being, exacerbating or ameliorating (and possibly preventing) disease or promoting its occurrence. ${ }^{4}$

A recent and compelling resource for reflection about this proposal is The Joy of the Gospel, Pope Francis's apostolic exhortation released in November 2013. The most basic message of the document is that the Gospel is good news in the deepest possible sense. It is the love of God in Jesus Christ for our liberation to new and authentic life. Hence their being in Christ is nothing other than the central source of joy in Christians' lives. But joy as an expression of one's own most being has an infectious quality, and the Gospel Christians are called forth boldly to proclaim is, in its true and manifest appearance, beautiful. So our going forth from ourselves to others in joy may not only prompt eager human interest; the beauty of the Gospel may yet elicit the love of it. Christian "missionary zeal" is for the sake of communicating the beauty of the Gospel, the beauty of life in Christ, joyfully. ${ }^{5}$

We do not and cannot do that if we are self-absorbed, indifferent, and "deadened" to the cry of the poor by our "culture of prosperity." But we may embody new life in Christ by acknowledging the extent to which we share and sustain a lifestyle which excludes others. We can give up defensively clouding over "something so simple and eloquent" as the claim that it is by the works of justice and mercy that we will be judged. "We may not always be able to reflect adequately the beauty of the Gospel, but there is one sign which we should never lack: the option for those who are least" (I94-I95). Beyond programs and specific practices of promotion and assistance, Christians need to nurture what Francis describes as an "attentiveness which considers the other in a certain sense at one with ourselves," and an appreciation of the poor in their goodness, experience, culture, and faith. True love has a "contemplative" character that permits us to serve another "not out of necessity or vanity, but rather because he or she is beautiful above and beyond mere appearances." 7

Is this the sort of "state of grace" that Marc Muskavitch has in mind? If so, then does his challenge to genetic determinism in terms of "mind-body interactions" hold in cases where a Christian life of missionary zeal takes us, but for the grace of God, where we

4 See above, page 18.

5 Pope Francis, The Joy of the Gospel, par. 42, 167, 264-265.

6 Pope Francis, The Joy of the Gospel, par. 54.

7 Pope Francis, The Joy of the Gospel, par. 199. 
wish not to go-to a life of sacrifice and even sorrow in self-giving, self-denying love? Can a life of attentive, self-emptying, suffering solidarity with others in their need and beauty really lead to mitigating rather than enhancing our genetic predispositions to disease?

I suppose that, of course it can. My point in this context is to insist that we not forget or slip past the complexity of discipleship. We lose our life and find it. Christians are called to be cheerful givers, and also to bear a cross. "Not to love anymore" is what Dorothy Day, quoting George Bernanos, called hell; but she was also fond of citing Dostoyevsky, who wrote that "love in practice is a harsh and dreadful thing compared to love in dreams." 8

8 Dorothy Day, Selected Writings, ed. Robert Ellsberg (Maryknoll, NY: Orbis Books, 1992), 85, 264. 